\title{
ADAPTIVE STRATEGIES FOR INLAND TOURISTIC DESTINATIONS (SIL CANYON, GALICIA, NW SPAIN) ${ }^{1}$
}

\author{
Elena De Uña-Álvarez* \\ Universidad de Vigo \\ Montserrat Villarino-Pérez** \\ Universidad de Santiago de Compostela
}

\begin{abstract}
Tourism potential is greatly related to destinations' reorganization and innovation abilities. Throughout the last fifteen years, tourism evolution at the western section of the Sil Canyon (NW Spain) has reflected the transformations facing times of crisis. By assuming tourism as a complex adaptive system, the aims of this research about an inland destination were focused on the touristic strategies interpretation. The destination evolution is carried out, including the narratives by key actors. The rural tourism strategies change by integrating nature-based and cultural tourism strategies.
\end{abstract}

Keywords: Inland Tourism, Touristic Destination, Key Actors, Crisis, Adaptive Strategies.

Estrategias adaptativas en destinos turísticos de interior (Cañón del Sil, Galicia, NO España)

\section{RESUMEN}

El potencial del turismo está relacionado en gran medida con la capacidad de reorganización e innovación de los destinos. Durante los últimos quince años, la evolución del turismo en el sector occidental del Cañón del Sil (Galicia, NO España) refleja las trans-

Recibido: 10 de mayo de 2016

Devuelto para su revisión: 11 de octubre de 2016

Aceptado: 30 de noviembre de 2016

1 The development of this research corresponds to the project CSO 2013-41374-R "Reconversión, revalorización y reinvención de espacios turísticos interiores de España. Análisis de casos y formulación de estrategias ante la crisis" funded by the Spanish Ministry of Economy and Competitiveness, in compliance with the call for "Retos Investigación", program targeting Challenges of Society (IPs G. Cànoves and A. Blanco, UAB).

"Departamento de Historia, Arte y Geografía. Campus de Ourense. Universidad de Vigo.E- mail: edeuna@uvigo.es

** Departamento de Geografía. Universidad de Santiago de Compostela. E-mal: montserrat.villarino@usc.es 
formaciones ante momentos de crisis. Asumiendo que el turismo es un sistema adaptativo complejo, los objetivos de esta investigación sobre un destino de interior están centrados en la interpretación de las estrategias turísticas. El estudio de la evolución del destino turístico incluye la lectura de los actores clave. Las estrategias de turismo rural cambian integrando las estrategias de turismo en la naturaleza y cultural.

Palabras clave: Turismo de interior, Destino turístico, Actores clave, Crisis, Estrategias adaptativas.

\section{INTRODUCTION}

The World Tourism Organization estimates that global international inbound tourists will increase 3.3\% annually between 2010 and 2030. Emerging destinations will represent an annual increase of $4.4 \%$ which means the double in relation to other destinations (UNWTO, 2015). The importance of tourism is even greater in Spain, where its direct contribution to the Gross Domestic Product reached $11.7 \%$ and generated one out of each seven job positions created in 2015 (Exceltur, 2016). Spain is one of the countries in the European Union with a higher percentage of domestic trips (84\%), together with Greece $(88 \%)$ and Romania (86\%). Most of national tourists visit destinations within their same region (Instituto de Turismo de España, 2015). The role developed by tourism as a driving force for socio-economical development is clear in autonomous regions such as Murcia, Aragón, Extremadura and Galicia (destinations where the year-on-year tourists increase in 2013-2014 exceeded 20\%). Therefore, inland spaces in Galicia are interesting territories to be studied in order to analyse evolution processes regarding tourism.

During the first decade of the $21^{\text {th }}$ century, given the socio-economic crisis, the main challenges that tourism had to face were reorganization or transformation in order to attract tourists to destinations other than sun/beach (alternative destinations); innovation in order to break seasonality and create synergies with other activities; and adaptation and change with regard to previous tendencies, considering the increasing weight of virtual information (Plan de Turismo en España Horizonte 2020 - Spain Horizon 2020 Tourism Plan). These challenges affect mainly inland spaces that focus their target on nature and rural touristic assets. In Galicia, the Integral Plan for Tourism 2014-2015 (Xunta de Galicia, 2014a) insists specially on the need for strengthening actions in order to elaborate a destination brand. However, adaptation, transformation and change of processes fostered by institutional administrators are strongly related to expectations and intervention ability of local actors.

The western area of the Sil Canyon (Cañón del Sil in Spanish and Canón do Sil in Galician language), between the provinces of Lugo and Ourense, is a singular space within inland Galicia. Belonging to the territory known as Ribeira Sacra, it was first made visible by the Galicia Rural Tourism Guide in 1996. The definition of Ribeira Sacra as a Geodestination (Xunta de Galicia, 2011) represents a touristic identity well differentiated within Galicia. This research aims at studying the evolution of touristic activity in this inland destination, even in times of crisis, and analysing the processes of reorganization 
and diversification of the territory with regard to tourism. Considering the theory of complex adaptive systems, tourism as a concept is defined by a social-ecological system. The methodology suggested for the analysis is intended to study and understand the processes that come together for the evolution of an inland touristic destination.

\section{THEORETICAL FRAMEWORK}

Inland territories are experiencing a significant revaluation of tourism, leading to transformations of territories themselves and their interaction with key actors. An explicit willingness exists to achieve sustainability of the destination, a key issue regarding resources protection, population maintenance and an adequate design of use/management plans. The configuration of strategies developed to meet that goal (Díez, 2013; Cànoves et al., 2014; López-Palomeque and Cànoves, 2014; Navarro, 2015) depends particularly on mobilization of available assets, acknowledgment of opportunities for touristic activities, and individual or collective incentives to change. From the theoretical perspective of tourism as a system (Leiper, 1990; Mill and Morrison, 2006; Pearce, 2012), those strategies reveal the potential for adaptation and improvement when facing critical events at different scales. At the same time, those strategies bring to light that tourism - when based on a holistic concept of territory - has a dynamic and relational meaning (Telfer and Sharpley, 2008; Muñoz, 2012).

According to terminology of General Systems Theory (Bertalanffy, 1968), tourism presents the properties of an open, dynamic, nonlinear, adaptive and complex system. Diversity of its space-time trajectories reflects the behavior of a group of interdependent elements where change processes are regulated in compliance with decisions made by social actors. The complex nature of tourism results mainly from the inevitable integration of ecologic, cultural, socio-economic and political dimensions at multiple scales. An integrated touristic development (Ávila and Barrado, 2005) rests on the collaboration among the agents being responsible of destinations' configuration. It contributes to revaluation of territorial heritage (Sancho and Vera, 2008; Du Cros and McKercher, 2015), strengthens identity (Martínez, 2013) and favors sustainability of weak territories (Rubio and Sanz, 2007; Torres, 2010; Williams and Lew, 2015). Some authors (Palmas et al., 2014) use the concept of harmonic tourism, a complex system also known as hommoecosystem. In those systems, integration of biophysical and human constituents acts as a pillar for local sustainability. The notion of tourism as a social-ecological system (SES) insists on considering multiple dimensions even if certain issues of special interest arise when analyzing processes of revaluation, transformation and reinvention of tourism for inland territories.

The definition of a SES (Glaser et al., 2008; Binder et al., 2013; McGinnis and Ostrom, 2014) refers to any functional unit with tangible and intangible resources, institutions and social actors, delimited by certain activities, conditions or problems. This definition emphasizes that evolution of natural systems and social systems is interdependent. Studies focused on dynamics of SES (Berkes et al., 2003; Cumming and Collier, 2005; Janssen et al., 2007; Nyaupane and Poudel, 2011) differentiate adaptive cycles with phases of growth, maintenance, reorganization, innovation or collapse of 
the system - all of them emerging as responses to critical situations. This approach is based on a wide concept regarding changing phenomena related to function, structure and identity of complex systems. Adaptive cycles were suggested, at the beginning, to study natural systems (Holling, 2001; Holling et al., 2002), by examining survival ability of ecosystems when facing determined critical events. Thus, when dealing with the analysis of tourism as a SES, it is common to encounter the concept of resilience (Tyrrell and Johnston, 2008; Strickland-Munro et al., 2010; Baral, 2013; Espiner and Becken, 2013; Luthe and Wyss, 2014). Among the multiple theoretical and methodological definitions of resilience (Carpenter et al., 2001; Walker et al., 2006; Resilience Alliance, 2007; Hudson, 2010; Folke et al., 2010; Wilding, 2011; Amat, 2013; Cumming et al., 2015), this research considers the one referring to territorial scope. That is, the definition related to dynamics of territory (a relational, dynamic system) when facing change within the context of tourism (a social-ecological system), and focusing evolution of an inland destination (Figure 1).

Figure 1

DESTINATION AS A SOCIAL-ECOLOGICAL SYSTEM

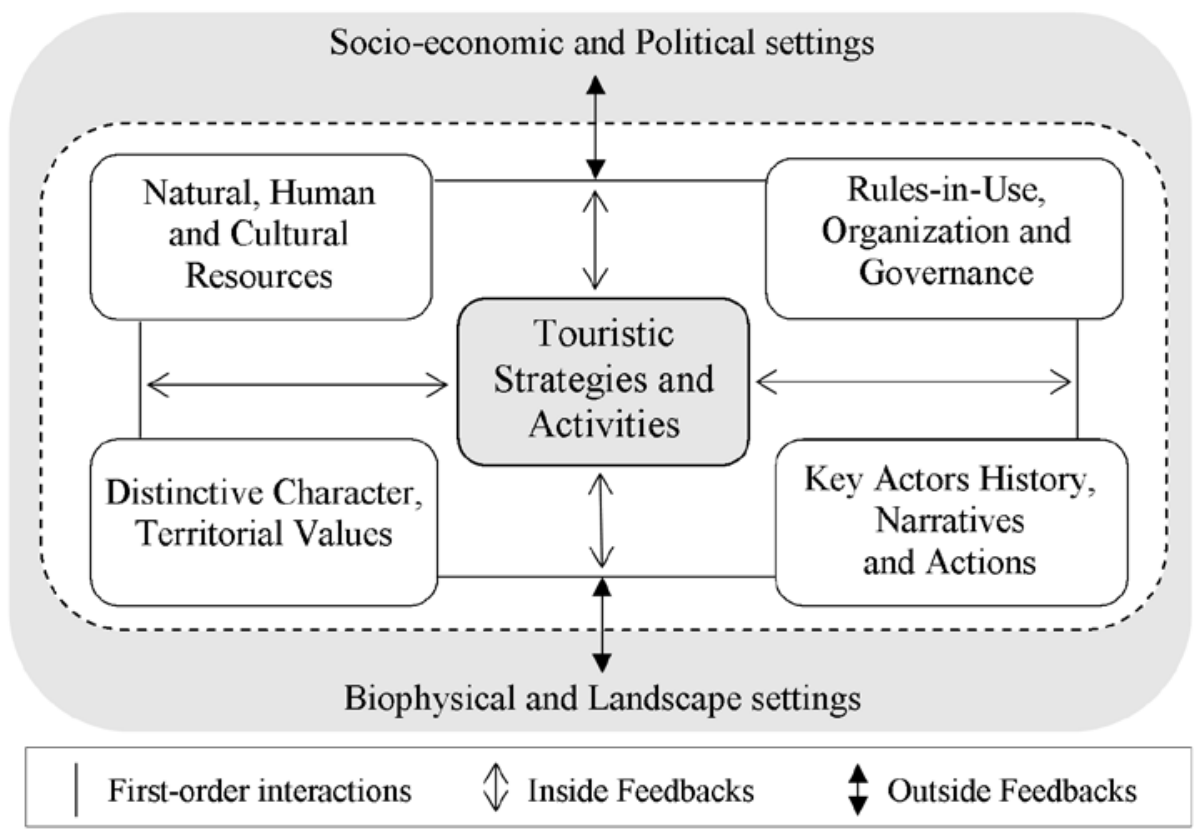

Source: Elaboration based on McGinnis and Ostrom (2014).

Destinations are of great interest since they represent a decisive component regarding most of the current challenges that tourism faces (Barrado, 2004; Vera et al., 2011) especially at a local scale. Relationships among the actors involved in the development and promotion of a destination generate different degrees of cohesion and stability with 
regard to touristic activity (Novelli et al., 2006; Merinero and Pulido, 2009; Crespo et al., 2014). The value chain of destinations is related to connections among socio-institutional actors, relationship networks and immediate/distant environment. The model for adaptive cycles was used on this research as a tool to elaborate diagnosis and to analyze evolution of tourism in compliance with the case study: a local inland space.

\section{METHODOLOGY}

This research was developed in three different stages starting from the methodology established by several authors in relation to the analysis of tourism as a SES (Berkes et al., 2003; Strickland-Munro et al., 2010; Luthe and Wyss, 2014). The first phase consisted in delimiting space of the studied system and defining its elements in order to carry out a diagnosis of its current state. Documentation resources and statistics were used during this stage together with a first fieldwork visit. Throughout the second stage, interaction among system elements was studied, considering from the last decade of the $20^{\text {th }}$ century. By such a study stage, key events and actors on the system's dynamics were identified. At that point, the research focused on detailed fieldwork and on information processing in order to define afterwards the potential adaptive cycles and their phases. Twelve thorough interviews to key actors were carried out (2011-2012) in compliance with methods by Cànoves et al. (2014). Next, the third methodological stage focused on the analysis of the system's evolution over the last fifteen years, taking into consideration critical events at different scales (external and internal) that affected adaptive strategies in relation to the touristic destination.

Following Walker et al. (2006) and Cumming et al. (2015), the cycles to be identified correspond to interactive processes (Fig. 2) with growth phases regarding capital and resources $(\mathrm{r})$, and followed by exploitation or maintenance of the system $(\mathrm{K})$ generating reorganization processes $(\Omega)$ in which there is a possibility of saturation or collapse. From these processes, reconstruction or reinvention of the system (a) arises by starting innovative approaches (Figure 2). Some events substantially alter this dynamics. In times of socio-economical crisis, the system may vary between (r) and (K) reflecting a mechanism for conservation, or may change from $(\mathrm{r})$ to $(\Omega)$ due to maintenance being impossible. Likewise, the emergence of new actors (social or political) may cause the $\mathrm{W}$ break. The inherent uncertainty of evolution in any complex system gives to this model a nonlinear nature, with self-organization dynamics. The evolution of a touristic destination according to this model reflects its adaptive ability when facing challenges. Nevertheless, Hinkel et al. (2015) consider that the study of the evolution of a SES must always be contextualized by the scope and intention of the analysis, insisting on the role played by territorial actors and governance processes. Regarding the case here presented, the analysis comes determined by local dimension, aiming at interpreting the current situation of the destination. Starting from the latest update of the framework regarding SES (McGinnis and Ostrom, 2014), the methodology applied seeks understanding processes of use and management of natural and human resources in relation to tourism - considering that biophysical, social, cultural and institutional context affects territorial actors (individual and collective) for making decisions. 
Figure 2

MAIN STRATEGIES IN THE ADAPTIVE MODEL

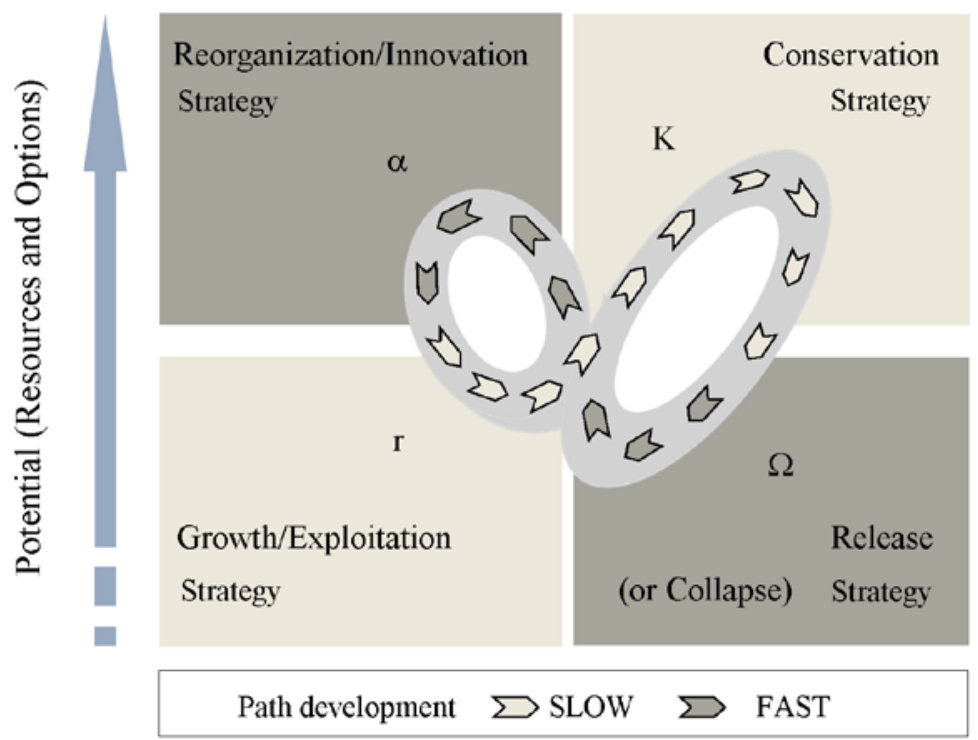

Source: Own elaboration based on Holling et al. (2002) and Cumming et al. (2015).

The variables used are related to the intention of detecting the adaptation ability of a particular touristic destination when facing diverse situations (Table 1). In order to select study indicators, proposals by Task Force on Core Social Variables (Eurostat, 2007), World Tourism Organization for sub-national analysis (UNWTO, 2013), the European Tourism Indicator System (Core Indicators, European Union, 2013 and 2016) and by the Xunta de Galicia (2015a) were considered, as well as some other specific studies on touristic destinations (Smith, 2015).

Table 1

\section{RESEARCH VARIABLES AND INDICATORS}

\begin{tabular}{|l|l|}
\hline Variable/Indicator & Scale/Information Source \\
\hline Resources & Study area and Municipal \\
Protected areas & \\
Natural and cultural heritage & Documental and Bibliographic research \\
Touristic products promoted & Websites \\
Tourism enterprises and associations & Local municipalities and communities \\
Tourism offices and other services & Field work \\
Key stakeholders & \\
\hline
\end{tabular}




\begin{tabular}{|l|l|}
\hline Variable/Indicator & Scale/Information Source \\
\hline Demographic & Study area, Municipal, Regional and \\
Total population (inhabitants number) & National \\
(TP) & Instituto Galego de Estatística (IGE) \\
Total population change (TPc) & Instituto Nacional de Estadística (INE) \\
Population density (inhab.km-2) (PD) & \\
Percentage population from $>64$ years & \\
(PP>64) & \\
\hline Socio-economic & Study area, Municipal, Regional and \\
Unemployment registered & National \\
Employment activity (SSA) by sectors & Instituto Galego de Estatística (IGE) \\
Urbanization degree & Instituto Nacional de Estadística (INE) \\
Number of accommodation & Agencia de Turismo de Galicia \\
establishments (Na) & Turgalicia \\
Accommodation establishments by types & Websites \\
Number of bed-places supplied (BP) & \\
Bed-places supplied by establishment & \\
type & \\
\hline $\begin{array}{l}\text { Socio-political } \\
\text { Influential legislation on territory and } \\
\text { tourism }\end{array}$ & Study area, Municipal, Regional, \\
Programs and plans affect local dynamics & Documentation research \\
Initiatives supported on local actors & Websites \\
Key actors narratives and prospective & Local municipalities and communities \\
Residents territorial identity & Field work \\
Residents satisfaction degree & \\
Events focused on assets or culture & \\
\hline
\end{tabular}

\section{CASE STUDY}

The Sil River is the major tributary to the main Galician fluvial channel, the Miño River. In the western area of the Sil valley nine municipalities focus their touristic offer on the territorial heritage values (Figure 3 ). Since the last decade of the $20^{\text {th }}$ century, both the northern municipalities (in the province of Lugo: Monforte de Lemos, Pantón, Ribas de Sil and Sober) and the southern municipalities (in the province of Ourense: Castro Caldelas, Nogueira de Ramuín, Parada de Sil, A Teixeira and San Xoán de Río) promote a nature, rural and cultural touristic destination. The surface extension reaches 880.90 $\mathrm{km}^{2}$ with a total of 30194 inhabitants (2015). This fluvial corridor (the Sil Canyon) is the natural border between two inland provinces. Their environmental value is acknowledged by the declaration of two Special Conservation Areas (Xunta de Galicia, 2014b): the Sil Canyon (covering areas of the councils of Pantón, Sober, Nogueira de Ramuín and Parada de Sil) and the valley of the Cabe River (covering areas of the councils of Monforte de Lemos, Pantón and Sober). The protected areas include most of the surface waters, rock 
escarpments, riverbank woodlands, oak woods, and chestnut woods (soutos), together with natural and semi-natural grasslands that represent 23 habitats and 28 taxa of interest in compliance with the European Directive 92/43/CEE. The selected territory for this research belongs to the landscape area of Ribeiras Encaixadas do Miño e do Sil, and is delimited by the Ribeira Sacra unit (Xunta de Galicia, 2015b). The vineyards on terraces (socalcos) and the historical-artistic elements related to monastic orders are of great significance to the landscape.

Figure 3

STUDY AREA

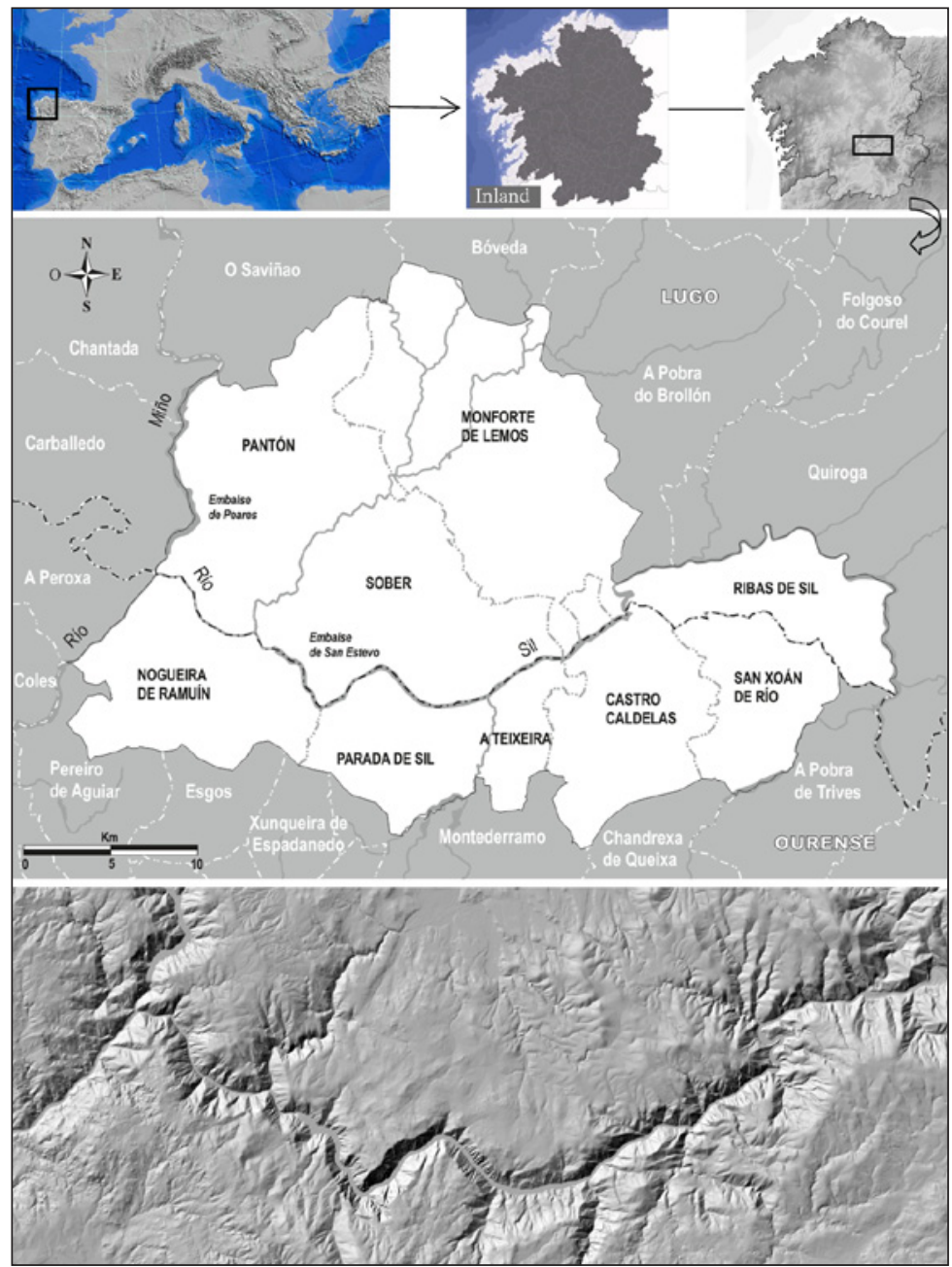

Maps Sources: Inland territory location and Western Sil Canyon relief from SITGA (Galician Territorial Information System); Case study area: Own elaboration. 
Given the rugged terrain and the isolation due to a hard access, this inland space in Galicia has remained for centuries as a hostile territory for human communities. Since the middle of the $20^{\text {th }}$ century, it has been subject to a great hydroelectric exploitation. The flow of the Sil River is regulated for that purpose by two dams, San Pedro (upstream the studied area) and San Estevo (within the studied area, $202 \mathrm{hm}^{3}$ ). Most of the villages do not reach 100 inhabitants and the administrative centers of Castro Caldelas (645 inhabitants) and Monforte de Lemos (16500 inhabitants) act as the main nodes for services provision (IGE, 2015). Tourism development, initiated as rural, has engendered a series of processes leading to transformation of an unattractive territory into a destination of an increasing demand.

\section{THE CHANGE MEANING: ADJUSTMENTS AND ADAPTIVE STRATEGIES}

\subsection{Destination diagnosis and evolution}

The main touristic elements comprised today within the resources used are nature and landscape. The fluvial canyon and waterfalls, the sunny rocky slopes (vineyards) or the shady areas (forests) form such a beautiful natural scene (Figure 4). Given the potential of panoramic views, the viewpoints (at both riverbanks) act as nodes for a touristic route bearing the same name. Besides, the dammed flow of the Sil River has three different fluvial piers from where visits by catamaran start. Among accommodation establishments the following stand out: the National Paradors of Santo Estevo (in Nogueira de Ramuín) and Monforte de Lemos, the Augas Santas Balneario \& Golf Resort (in Pantón), and the Os Bioscos nature inn hotel (in San Xoán de Río). A total of 16 touristic routes, two of which surround the canyon, are promoted by public agents (Turgalicia, Diputación de Lugo, Diputación de Ourense, and town councils), associations and clubs (mountaineering, canoeing). This destination includes two authorized short-distance trails and is recognized by the Spain Nature Trails network as the Camino Natural de la Ribeira Sacra (Ministerio de Agricultura, Alimentación y Medio Ambiente). The association Amigos del Camino de Santiago has been promoting the trail known as Camino de Invierno (Camiño de Inverno) along the northern riverbank. Every town council involved has its own tourism office. The study area belongs to the Geodestination Ribeira Sacra, whose promotion highlights the following elements: the Sil Canyon, the route by catamaran, vineyards and their wine protected with designation of origin, festivities declared as to be of Touristic Interest (Feira do viño de Amandi, Amandi Wine Fair) in Sober, patrimonial heritage such as monasteries and touristic routes.

The degree of urbanization is low, as it corresponds to thinly-populated areas with a population density $<100$ inhab $\mathrm{km}^{-2}$. Only Monforte de Lemos and its surroundings reach an average degree of urbanization (intermediate-populated area). Surface extension of artificial and constructed land (quarries, dams, buildings) is $<10 \%$ in all the municipalities. Active population (Table 2) is employed similarly to what happens at regional and state level, with a higher representation in the services sector. 


\section{Figure 4 \\ DESTINATION VIEWS}

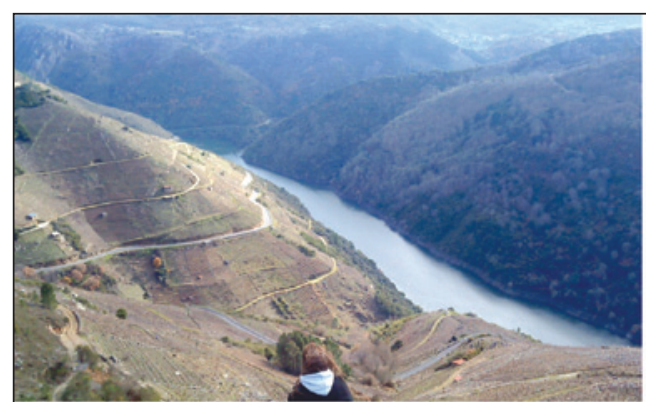

Riversides of the Sil Canyon (from West)

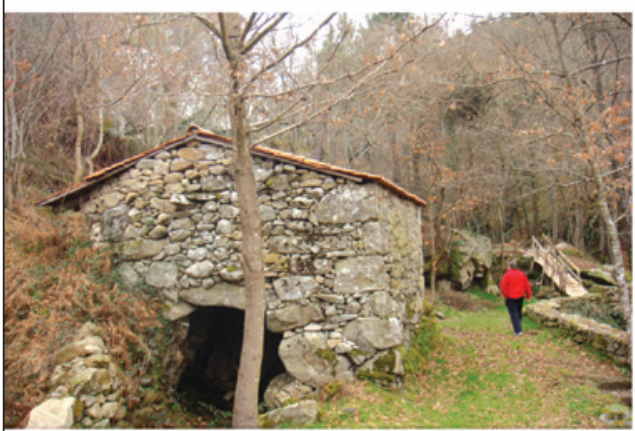

Water Mills (Xábrega, Sober)

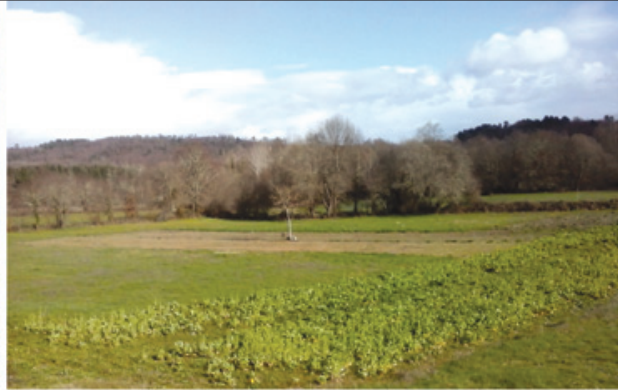

Rural Landscape of the upper plains

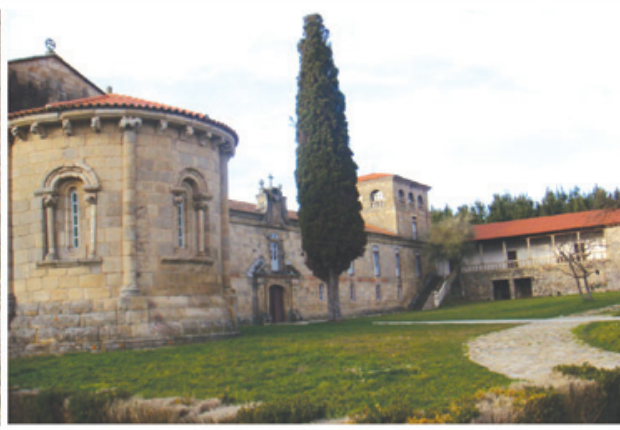

Bernardas Monastery (Cistercian Order, Pantón)

Table 2

EMPLOYMENT ACTIVITY BY SECTORS (2015)

\begin{tabular}{|c|c|c|c|c|c|c|}
\hline TERRITORY & SSA & A & I & C & S & T \\
\hline Study area & 8.798 & 6 & 11 & 9 & 75 & 100 \\
\hline Galicia & 932.992 & 6 & 14 & 7 & 72 & 100 \\
\hline Spain & 16.556 .000 & 7 & 12 & 6 & 75 & 100 \\
\hline
\end{tabular}

$\mathrm{SSA}=$ Number of Social Security Affiliations, then by sectors (\%): A=Agriculture and Fishing, I=Industry, $\mathrm{C}=$ Construction, $\mathrm{S}=$ Services, $\mathrm{T}=$ Total employment. Sources: IGE, INE (Own elaboration).

The negative trend regarding population during the last fifteen years (Table 3) represents a loss of 4775 inhabitants in relation to data of the year 2000 (34949 inhabitants). Currently, the total population represents only the $1 \%$ of Galician population. The population density, also declining, is much lower than the values representing the total of Galicia (92.39 in 2015). The high percentage represented by population of 64 years or older exceeds always that of the whole autonomous region, for which the percentage in 
2015 is $24 \%$ (a total of $18.5 \%$ in Spain). In addition to the critical situation reflected by the evolution of population indicators, unemployment rate is also to be taken into account. Nevertheless, this latter indicator has suffered an increase rate regarding the studied target (1.57) inferior to that of Galicia (1.71) - should the date of 2000 (scale 100) be used as initial reference. At the same time, the offer with regard to accommodation has experienced an ongoing increase despite the economic crisis. Its variation rate between 2003 and 2015 (2.75) has remained slightly inferior to that of Galicia (2.94) even though there was a significant break in 2008 (Fig. 5a). Most of the increasing offer is related to hotels, inns and guesthouses (Table 4). Over the time period studied, such an accommodation category has been gaining significance over rural tourism offer. The latter has decreased its participation $(2003=50 \%)$ since $2009(31 \%)$ until $2015(27 \%)$.

Table 3

EVOLUTION OF DEMOGRAPHIC INDICATORS

\begin{tabular}{|l|c|c|c|c|c|c|c|c|}
\hline INDICATOR & 2001 & 2003 & 2005 & 2007 & 2009 & 2011 & 2013 & 2015 \\
\hline TP & 34.859 & 34.054 & 33.416 & 32.681 & 32.299 & 31.864 & 31.088 & 30.194 \\
\hline TPC & 0,99 & 0,97 & 0,96 & 0,94 & 0,92 & 0,91 & 0,89 & 0,86 \\
\hline PD & 39,57 & 38,66 & 37,93 & 37,10 & 36,67 & 36,17 & 35,29 & 34,28 \\
\hline PP $>64$ & 34 & 35 & 36 & 36 & 36 & 35 & 34 & 34 \\
\hline
\end{tabular}

$\mathrm{TP}=$ Total population, $\mathrm{TPC}=$ Total population change $(2000=100), \mathrm{PD}=$ Population density, $\mathrm{PP}>64=$ Percentage of population $>64$ years. Source: IGE (Own elaboration).

Table 4

EVOLUTION OF SOCIO-ECONOMIC INDICATORS

\begin{tabular}{|l|c|c|c|c|c|c|c|}
\hline INDICATOR & 2003 & 2005 & 2007 & 2009 & 2011 & 2013 & 2015 \\
\hline $\mathrm{Na}$ & 26 & 27 & 30 & 43 & 45 & 52 & 67 \\
\hline $\mathrm{NaG}$ & 1.135 & 1.335 & 1.518 & 2.754 & 2.888 & 3.002 & 3.339 \\
\hline $\mathrm{NaR}$ & 13 & 13 & 14 & 15 & 15 & 17 & 18 \\
\hline $\mathrm{BP}$ & 678 & 872 & 1.134 & 1.207 & 1.370 & 1.456 & 1.866 \\
\hline $\mathrm{BPG}$ & 78.505 & 84.469 & 90.509 & 115.407 & 119.459 & 123.853 & 125.059 \\
\hline
\end{tabular}

$\mathrm{Na}=$ Number of accommodation establishments, $\mathrm{NaG}=$ Number of accommodation establishments in Galicia, $\mathrm{NaR}=$ Number of Rural Tourism establishments, BP=Bed-places supplied, BPG=Bed-places supplied in Galicia. Source: IGE, Turgalicia (2015 data) (Own elaboration).

Regarding accommodation, most of the vacancies include offer from hotels, inns, apartments and guesthouses (Fig. 5b). Between 2003 and 2007 this category represents $65-69 \%$ of the total offer, especially significant since 2009 (82\% of the total) until current times. Vacancies in hotels at Monforte de Lemos (Lugo) and Nogueira de Ramuín (Ourense) accumulated $75 \%$ of the total offer until 2005. Since the year 2007 such an offer reaches $90 \%$ of this type of accommodation together with the council of Pantón (Lugo). The explanation lies on the relevance of the offer by National Paradors and the Augas 
Santas Balneario \& Golf Resort. The percentage over the total number of vacancies offered corresponding to rural accommodation, however, has decreased since 2003 (24\%) until 2011 (16\%), slightly recovering (17-18\%) since 2013. Accommodation facilities offering rural tourism vacancies are concentrated (more than $80 \%$ ) in councils within the protected area (Nogueira de Ramuín, Parada de Sil, Sober and Pantón).

\section{Figure 5}

\section{LODGINGS AND BED-PLACES SUPPLIED}

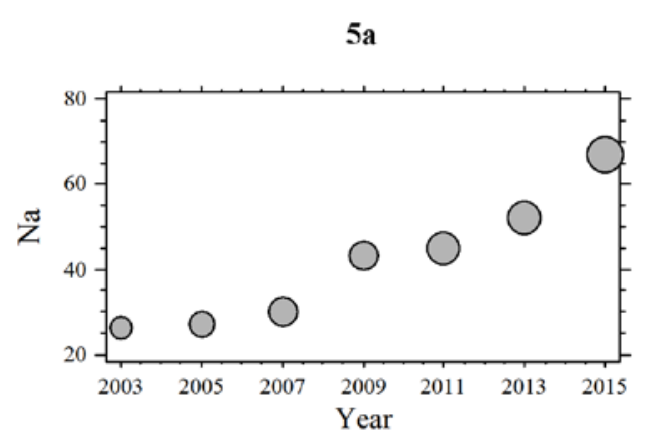

Bubble size for Na represents the bed-places increase (maximum aspect ratio $=10 \%$ )

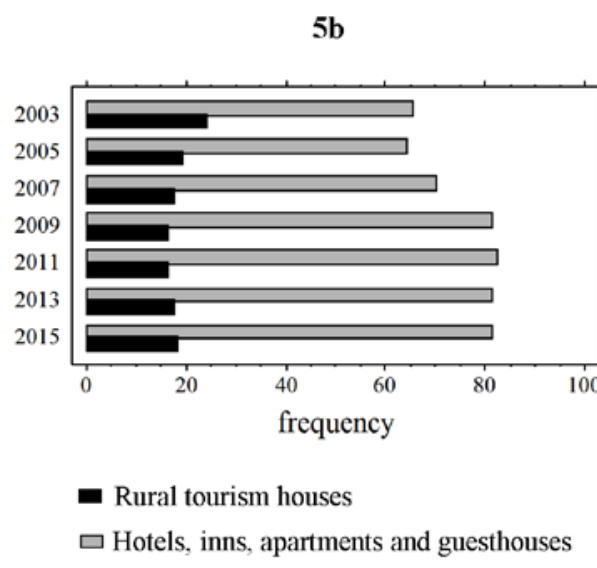

$\square$ Hotels, inns, apartments and guesthouses

Source: IGE (2003-2013 data) and Turgalicia (2015 data), own elaboration.

Although depopulation and ageing have not been curbed yet, European programs have become the major drivers for change. The Leader Plus (2000-2006) helped take action towards environmental improvement and revaluation of cultural heritage. The New Leader (2007-2013) encouraged processes of tourism diversification (of both rural and cultural nature). On the other hand, the creation of companies working at state scope has favored the increase of vacancies offered, renovation of buildings with a unique historicalartistic value, and the inclusion of the destination into networks acknowledging touristic quality as National Paradors, Oca Balnearios and the Asociación Innovadora Termal de Galicia (Galicia Thermal Innovative Association). The definition of the studied area as a Geodestination (Xunta de Galicia, 2011) creates a new scene for promotion. Regional administration and the Agencia Gallega de Desarrollo Rural (Galician Agency for Rural Development) have already started in 2007 an action plan aiming at invigorating rural inland spaces (Programa de Desarrollo Rural de Galicia 2007-2013 and 2010-2014). In the mentioned action plan, the western section of the Sil Canyon appeared included as a high-priority area (Terras do Sil - Depresións ourensáns, Ourense) and intermediate-priority area (Lugo sur). Regarding this destination, the Plan de Dinamización Turística (20062009 Touristic Dynamization Plan) coordinated by the Ribeira Sacra Tourism Board and the governing council of the Ribeira Sacra Designation of Origin had great significance. 


\subsection{Interpretation of key actors}

Narration of events, processes and evolution of the destination by local actors is fundamental to learn the meaning and scope of adaptive strategies. The information drawn from thorough interviews provides a tale in which territorial identity, acknowledgement of unique resources and expectations on tourism - whether or not they have been fulfilledcoexist. Key actors express it that way when talking about the beginnings of touristic activity and the evolution of these destinations:

«...late $80 \mathrm{~s}$, at that time many courses on rural tourism were offered; during the Silleda trade fair Turisport used to be held (...) Then, people - especially young people - felt rooted to their land, and if they had studies, because we are talking about times when a lot of people were educated, that was vital in order to value and appreciate all that (...) In the year 88 , for some conferences on Art, university teachers came to talk and so on; and there was no place where to take them for sleeping or eating besides the town council administrative centre. There were some places in Monforte, you know. Today, for instance, there are two National Paradors in the region, a 4-star spa in Pantón, several cottages for rural tourism...» (I2, Native resident, high-school teacher)

«Before coming I had no idea (...) It is a spot protected within Spain. That is why, I think, it is untransformed, with naiveté. If many people came here, the place would get ruined. But I think more people are needed here, more employment opportunities, more industries. There are also opportunities to work the field and do different stuff (...) During the 7 years I have been here, trees have grown and fields keep disappearing (...) Some people have pictures of this area, pictures from 50 years ago, and there are a lot of trees but not as many as there are now (...) People need to go out, leave and come back. They do not value what they have. » (I11, Foreigner resident, enterprise owner)

The most valuable resources and the narration of the events clearly define the effects on mobilization and integration of touristic strategies at the destination when facing extreme conditions:

«...the Sil Canyon, well... it is an area of an unrivalled landscape and well, that is its strongest point, isn't it? »(I3, No-native, business manager) and also «... important, to be preserved, very important its architecture, to preserve the territory, the terraces and all that, the landscape (...) Well, truth is that it is something that exists in other places, but to this place it is something new, an innovation. Trail routes are being improved, but slowly. » (I2, Native resident, high-school teacher)

«The National Parador is a destination itself (...) most of the initiatives emerged did so thanks to people who were not directly related to the place... At the beginning it was a boom regarding rural tourism, European projects (...) everything is 
strongly linked to European projects. The first Leader projects provided a lot of money to build rural accommodation facilities, restaurants, wine cellars, trail routes. That was the boom. » (I6, Native, public administration manager)

«First it was the catamaran and later Romanesque and trekking, but everything developed slowly (...) A great boost was the wine governing council. It encouraged the creation and acknowledgement of the Ribeira Sacra brand; it promoted that idea and step by step we all started to engage with it... The brand was going well, people seemed to enjoy it and now we all support that. Today it is easy to find it in shops and believe or not people get more and more involved with the time. » (I1, Native resident, public administration manager)

Likewise, a clear awareness of the problems, handicaps and needs is stated regarding territorial cohesion and innovation in order to achieve a competitive positioning:

«We are now facing hard times due to the current crisis (...) at this moment we either improve or fall down, you know? » (I3, No-native, business manager)

«I think that we must word hard to create a more comprehensive product. Here we face the problem with localism. In my opinion it is something very Galician because we are all like that... So we must work in that direction because I think there are many differences... We must try hard... getting all involved with the project. » (I8, No-native, public administration manager) and « actions must integrate every citizen. » (I4, Native resident, public administration manager)

«We build a riverside walk, some works... but that is not enough, that isn't interpreting heritage. It is something different, neither good nor bad, just something else. Here we are mixing concepts (...) Emotion is key, evoking that emotion: a call, touching people's feelings, make them understand what they are contemplating, make them understand where all that comes from, make them get to know the village, the region, the area (...) You know, we will always have to pay, of course. But there is no point in having millions, if we don't know how to prepare things. » (I9, No-native, journalist)

\subsection{Adaptive strategies}

Among the processes that mark the takeoff of tourism we can highlight the creation of a wine origin designation (Ribeira Sacra, 1995), producing significant changes in relation to land use. Surface devoted to vineyards tripled between 1992 (300 ha) and 1996 (900 ha) and nowadays it exceeds one thousand hectares (1258 ha in 2014). Besides the production increase, this process leaded to an increase in the number of vine growers (from 1100 in 1996 to 2674 in 2014) and the number of wine cellars: the 55 existing in 1996 to double in 2008 (98 cellars) and a total 89 currently functioning. In addition to productive functioning, wine acts as an appeal for touristic visits to the cellars, as promoted by 
the Consejo Regulador de la Denominación de Origen (governing council of the origin designation). Moreover, the presence of the destination in the Guía de Turismo Rural de Galicia (Galician Rural Tourism Guide, Turgalicia, 1996) was the starting point for its promotion as a singular destination. Also, since the beginning of the $90 \mathrm{~s}$, the European programs such as Leader (1991-1994) and Leader II (1994-1999) encouraged improvements in signaling, houses and cottages renovation for rural tourism accommodation and awareness campaigns addressed at local actor regarding territorial heritage value. The proposal about the Western Sil Canyon as a place of importance for the Nature 2000 network by the regional government (Xunta de Galicia) in 1999 represented, likewise, an event that brought environmental value to the destination. The effects reached subsequently by events within the field of governance and reorganization of touristic strategies favored the understanding of the destination's evolution.

Processes developed during the final years of the $20^{\text {th }}$ century define the initial conditions of a development phase that helped increase natural and socio-economic capital at the same time that positioning strategies focused on rural tourism until the crisis starts to be noticed (Figure 6). Between 2001 and 2007 the number of buildings refurbished in the studied area increased from 8 to 34 and two lodging establishments were opened in emblematic buildings. The growth rate of bed-places supplied during those years (1.67) exceeded that of the total in Galicia (1.15) and the destination was first presented at the national tourism fair. Furthermore, the western area of the Sil Canyon was declared Zona de Especial Conservación de Valores Naturales (Special Conservation Area for its Natural

\section{Figure 6 \\ ADAPTIVE STRATEGIES OF THE DESTINATION}

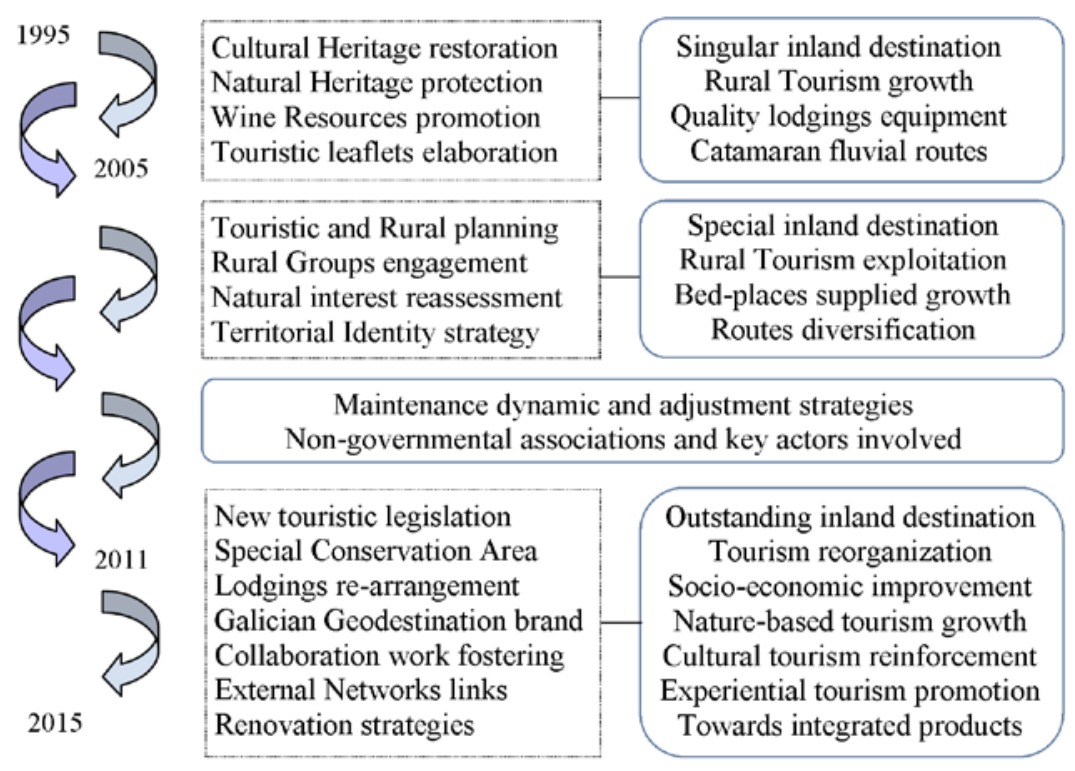


Value) by the Xunta de Galicia in 2004. Over these years previous to the socio-economic recession, growth and maintenance of touristic activity was mainly supported by the Leader Plus European program with two Local Action Groups: Ribeira Sacra in Lugo and Pais do Bibei in Ourense. A touristic map was created, promoting the routes by catamaran and the destination itself.

Determined by subsequent critical times, a touristic dynamization plan was drawn for 22 municipalities in the area (2006-2009) upon agreement of collaboration among the Spanish Ministry of Industry, Tourism and Commerce, the Galician Regional Ministry of Innovation and Industry, the Lugo Business Association and the Ourense Business Confederation. Little did results match the plan expectations, due to a lack in social cohesion. Once in force the New Leader European program - with three different Groups for Rural Development sharing the studied territory - Galician legislation on tourism (2008) reorganized the classification of accommodation offer. Wine keeps being present as a touristic appeal, the Asociación de Amigos da Ribeira Sacra (Association of friends of Ribeira Sacra) was founded and, helped by the celebration of a Holy Year for Pilgrims (2010), the initiative Camiño de Inverno was born along the northern riverbank. However, between 2007 and 2011 the number of buildings renovated decreases from 34 to 16, and the growth rate for accommodation offer falls to 1.20 , being inferior to the Galicia rate (1.31). Thorough interviews carried out reflect the concerns caused by the economic crisis and the urge to seek new maintenance or transformation strategies.

The end of the New Leader and the Galicia Rural Development Program in 2013, together with the definition of the destination and the surrounding as Geodestination Ribeira Sacra in 2011 (as a touristic brand conceived as an opportunity for cooperative work regarding governance) welcomed a new strategy. For instance, the renovation of the Santo Estevo National Parador, including products related to spa, or the promotion of golf as a sport to be practiced at Augas Santas (very successful indeed) reflect renovation and creation strategies of an increased value. The inclusion of the destination in the program Caminos Naturales de España (2011) follows the same direction. Between 2011 and 2015 the accommodation offer increased again (1.36) more than the Galician global rate (1.05) The last Galician regional decree on the Natura Network declares the protected area as Special Protection Area, and the Galician integral tourism plan encourages the promotion of alternatives to coastal destinations. These conditions represent new opportunities to design strategies that include interesting resources in relation to integrated touristic products able to meet needs at different scales. Regarding our case study, current strategies target contemplative tourism (viewpoints) and experiential tourism (spa resorts, sports, trails). Those strategies come immerse in nature and culture of the destination. They represent the current state of a social-ecological system that has experienced growth, maintenance, adjustment, reorganization and reconstruction phases.

\section{CONCLUDING REMARKS}

Initial conditions of an inland, peripheral territory which limits human activity and presents a low degree of transformation, became strong points after the evolution of the destination studied. Those strengths get linked to a complex of values for touristic activity: 
a high-quality natural space at a moment when demand appreciates that type of territories, and socio-political actions are addressed at functional revitalization and encouragement of sustainable use and management. Tourism development — promoted by public and private sectors - focuses first on rural tourism. Such a strategic approach follows the same goals and expectations of other European rural spaces, being funding and investment main responsibility of public funds from Leader programs.

Interactions among external and internal actors focus on the studied touristic destination leading to specific situations since the beginning of the $21^{\text {st }}$ century. The case study reflects the development of processes such as growth, exploitation and maintenance. These processes precede and characterize the first years of the socio-economic crisis. In particular, the wine sector presents a new dynamics certifying itself as key resource for tourism and providing the destination with comparative advantages regarding the surroundings. Likewise, the role played by natural resources, especially those protected due to their environmental value, is crucial to understand why and how the touristic offer is still available, as well as the changes towards touristic products integrating nature, rural and cultural assets during the following years. The reorganization process started throughout the second decade of the $21^{\text {st }}$ century aims at facing the challenges given by the crisis, from which strategies emerge seeking innovation. In compliance with these strategies, processes of transformation and creation of added value to accommodation premises leads to a positive impact.

Nevertheless, these dynamic tendencies prove the divide in relation to demographic evolution of the destination. Delimited in an inland rural territory, the destination has a decreasing and more aged population. Obviously, such a situation must be understood as a constant within the demographic dynamics of the whole Galician territory. On the other hand, it seems hard to break the trend of depopulation and ageing that has settled for the last 15 years. Even so, the major brake for tourism development regarding the case study is the lack of cohesion within territorial government institutions. Such a weakness - even though, as a whole, the balance is positive - forms a strong barrier for the design and the launch of initiatives within the framework of touristic strategies development. Anyway, within the brand Galicia, this destination has becomes one of the major assets.

The analysis of the evolution of the western Sil Canyon area as a touristic destination, starting from the concept and characterization of it as socio-ecologic system, reveals the potential of such an approach in order to learn about tourism dynamics. However, results show the importance of considering interactions among elements within a specific context, both regarding the starting hypothesis and methodology. Applying an adaptive model in this case proves a significantly slow development process due to communication and coordination problems among the actors involved therein. Particularly, focus is set on research about tourism development and the role of local actors. Interaction among these actors supports valuable resources, is responsible for their mobilization towards integrated touristic products, and forms the basic network for the organization of a touristic micro-cluster at the destination - encouraging to a greater or lesser extent its promotion on virtual networks. Taking a closer look to these issues lays the foundation towards the goals and approaches of future research with regard to this field. 


\section{REFERENCES}

AMAT MONTESINOS, X. (2013): La resiliencia del territorio alicantino. Una interpretación geográfica ecocrítica. Tesis Doctoral. Universidad de Alicante.

ÁVILA BERCIAL, R. and BARRADO TIMÓN, D. (2005): «Nuevas tendencias en el desarrollo de destinos turísticos: marcos conceptuales y operativos para su planificación y gestión». Cuadernos de Turismo, $\mathrm{n}^{\circ}$ 15, pp. 27-44.

BARAL, N. (2013): «Evaluation and resilience of ecotourism in the Annapurna Conservation Area, Nepal». Environmental Conservation, n 41(1), pp. 84-92.

BARRADO TIMÓN, D.A. (2004): «El concepto de destino turístico. Una aproximación geográfico-territorial». Estudios Turísticos, n 160 , pp. 45-68.

BERKES, F.; COLDING, J. and FOLKE, C. (Eds.) (2003): Navigating Social-Ecological Systems. Cambridge, University Press.

BERTALANFFY, L.W. (1968): General System theory: Foundations, Development, Applications. New York, George Braziller. Available in http://suang.com.ar/web/wp-content/ uploads/2009/07/tgsbertalanffy.pdf1968

BINDER, C.R.; HINKEL, J.; BOTS, P. and PAHL-WOSTL, C. (2013): «Comparison of Frameworks for Analyzing Social-Ecological Systems». Ecology and Society, ${ }^{\circ} 18(4)$. Available in http://dx.doi.org/10.5751/ES-05551-180426

CÀNOVES, G.; VILLARINO, M.; BLANCO, A.; DE UÑA, E. and ESPEJO, C. (2014): Turismo de interior: renovarse o morir. Valencia, Publicaciones de la Universitat de Valencia, Colección Desarrollo Territorial (12).

CARPENTER, S.; WALKER, B.; ANDERIES, J.M. and ABEL, N. (2001): «From Metaphor to Measurement: Resilience of What to What? ». Ecosystems, n ${ }^{\circ}$ 4, pp. 765-781

CRESPO, J.; SUIRE, R. and VICENTE, J. (2014): «Lock-in or lockout? How structural properties of knowledge networks affect regional resilience». Journal of Economic Geography, nº 14, pp. 199-219.

CUMMING, G.S . and COLLIER, J. (2005): «Change and Identity in Complex Systems». Ecology and Society, $\mathrm{n}^{\circ}$ 10(1). Available in http://www.ecologyandsociety.org/vol10/ iss $1 / \operatorname{art} 29 /$

CUMMING, G.S.; ALLEN, C.R.; BAN, N.C.; BIGGS, D.; BIGGS, H.C.; CUMMING, D.H.; DE VOS, A.; EPSTEIN, G.; ETIENNE, M.; MACIEJEWSKI, K.; MATHEVET, R.; MOORE, C.; NENADOVIC, M. and SCHOON, M. (2015): «Understanding Protected Area Resilience: a multi-scale, social-ecological approach». Ecological Applications, $\mathrm{n}^{\mathrm{o}}$ 25(2), pp. 299-319.

PALMAS, Y.D.; SERRANO-BARQUÍN, R.C.; GASTÓN, J.; CRUZ, G. and FAVILA, H. (2014): «Modelo teórico-metodológico para el estudio del turismo armónico y el desarrollo local.» Investigaciones Turísticas, $\mathrm{n}^{\circ}$ 7, pp. 23-46.

DÍEZ, D. (2013): «La planificación estratégica en espacios turísticos de interior: Claves para el diseño y formulación de estrategias competitivas». Investigaciones Turísticas, $\mathrm{n}^{\mathrm{o}} 1(1)$, pp. 69-92.

DU CROS, H. and McKERCHER, B. (2015): Cultural Tourism. London, Routledge.

ESPINER, S. and BECKEN, S. (2013): «Tourist towns on the edge: conceptualizing vulnerability and resilience in a protected tourism system». Journal of Sustainable Tourism, $\mathrm{n}^{\circ}$ 22(4), pp. 646-665. Available in http//dx.doi.org/10.1080/09669582.2013.855222 
EUROPEAN COMISSION (1992): Council Directive 92/43/EEC of 21 May 1992 on the conservation of natural habitats and of wild fauna and flora (consolidated version). Available in http://eur-lex.europa.eu/legal-content/EN/TXT/?uri=CELEX:019 92L0043-20130701

EUROPEAN UNION (2013): The European Tourism Indicator System. Toolkit for Sustainable Destinations. Luxembourg, Publications Office of the European Union. Available in http://ec.europa.eu/growth/sectors/tourism/offer/sustainable/indicators/ index_en.htm

EUROPEAN UNION (2016): The European Tourism Indicator System. ETIS Toolkit for Sustainable Destination Management. Luxembourg, Publications Office of the European Union. Available in http://ec.europa.eu/growth/sectors/tourism/offer/sustainable/ indicators/index_en.htm

EUROSTAT (2007): Task Force on Core Social Variables-Final Report. Luxembourg, Eurostat Methodologies and Working Papers. Available in http://ec.europa.eu/eurostat/ en/web/products-manuals-and-guidelines/-/KS-RA-07-006

EXCELTUR (2016): Valoración empresarial de 2015 y perspectivas para 2016. Perspectivas turísticas, $\mathrm{n}^{\circ}$ 55. Available in http://www.exceltur.org/wp-content/uploads/2015/01/ Informe-Perspectivas-N51-Balance-2014-y-perspectivas-2015-Definitivo-Web.pdf

FOLKE, C.; CARPENTER, S.R.; WALKER, B.; SCHEFFER, M.; CHAPIN, T.; and ROCKSTRÖM, J. (2010): «Resilience Thinking: Integrating Resilience, Adaptability and Transformability». Ecology and Society, n ${ }^{\circ}$ 15(4). Available in http://www.ecologyandsociety.org/vol15/iss4/art20/

GLASER, M.; KRAUSE, G.; RATTER, B. and WELP, M. (2008): «Human-Nature Interaction in the Anthropocene - Potential of Social-Ecological Systems». Gaia, n 1/08, pp. 77-80.

HINKEL, J.; COX, M.E.; SCHÜLTER, M.; BINDER, C.R. and FALK, T. (2015): «A diagnostic procedure for applying the social-ecological systems framework in diverse cases». Ecology and Society, $\mathrm{n}^{\circ}$ 20(1), 32. Available in http://dx.doi.org/10.5751/ ES-07023-200132

HOLLING, C.S. (2001): «Understanding the complexity of economic, ecological, and social systems». Ecosystems, no 4, pp. 390-405.

HOLLING, C.S.; GUNDERSON, L.H. and PETERSON, G.D. (2002): «Sustainability and panarchies», in Gunderson and Holling (Eds.) Panarchy: understanding transformations in human and natural systems. Washington DC, Island Press, pp. 63-102.

HUDSON, R. (2010): «Resilient regions in an uncertain world: wishful thinking or a practical reality? ». Cambridge Journal of Regions, Economy and Society, $\mathrm{n}^{\circ} 3$, pp. 11-25.

INSTITUTO DE TURISMO DE ESPAÑA (2015): España en Europa. Madrid, Ministerio de Industria, Energía y Turismo. Available in http://estadisticas.tourspain.es/es-ES/ estadisticas/analisisturistico/espanaeneuropa/anuales/Espa\%C3\%B1a\%20en\%20 Europa\%202014.pdf

INSTITUTO GALEGO DE ESTATÍSTICA (2015): Estatísticas de Galicia. Availables in http://www.ige.eu/web/

INSTITUTO NACIONAL DE ESTADÍSTICA (2015): Estadísticas de España. Availables in http://www.ine.es/ 
JANSSEN, M.A.; ANDERIES, J.M. and OSTROM, E. (2007): «Robustness of socialecological systems to spatial and temporal variability». Society and Natural Resources, $\mathrm{n}^{\mathrm{o}}$ 20(4), pp. 307-322. Available in http://dx.doi.org/10.1080/08941920601161320

LEIPER, N. (1990): «Tourist attraction systems». Annals of Tourism Research, ${ }^{\circ}$ 17(3), pp. 367-384.

LÓPEZ-PALOMEQUE, F. and CÀNOVES, G. (Eds.) (2014): Turismo y territorio. Innovación, renovación y desafíos. Valencia, Tirant Humanidades.

LUTHE, T. and WYSS, R. (2014): «Assessing and planning resilience in tourism». Tourism Management, $\mathrm{n}^{\circ}$ 44, pp. 161-163.

McGINNIS, M.D. and OSTROM, E. (2014): «Social-ecological system framework: initial changes and continuing challenges». Ecology and Society, n 19(2), 30. Available in http://dx.doi.org/10.5751/ES-06387-190230

MARTINEZ, A. (2013): «Turismo de interior, identidad y cultura glocal. Valoraciones y propuesta», in Melgosa (Coord.) Turismos de interior. Madrid, Síntesis, pp. 43-77.

MERINERO, R. and PULIDO, J.I. (2009): «Desarrollo turístico y dinámica relacional. Metodología de análisis para la gestión activa de destinos turísticos». Cuadernos de Turismo, no 23, pp. 173-193.

MILL, R.C. and MORRISON, A.M. (2006): The Tourism System. Dubuque, Kendall/Hunt Publishing Company, $5^{\text {th }}$ edition.

MINISTERIO DE AGRICULTURA, ALIMENTACIÓN Y MEDIO AMBIENTE (MAGRAMA) (2016): Programa de Caminos Naturales. Available in http://www. magrama.gob.es/es/desarrollo-rural/temas/caminos-naturales/

MUÑOZ, A.I. (2012): «Análisis relacional de sistemas turísticos». Tourism \& Management Studies, no 8, pp. 55-64.

NAVARRO, D. (2015): «Recursos turísticos y atractivos turísticos: conceptualización, clasificación y valoración». Cuadernos de Turismo, n 35, pp. 337-357.

NOVELLI, M.; SCHMITZ, B. and SPENCER, T. (2006): «Networks, clusters and innovation in tourism: A UK experience». Tourism Management, $\mathrm{n}^{\circ} 27, \mathrm{pp} .1141-1152$.

NYAUPANE, G.P. and POUDEL, S. (2011): «Linkages among biodiversity, livelihood, and tourism». Annals of Tourism Research, $\mathrm{n}^{\circ}$ 38(4), pp. 1344-1366.

PALMAS, Y.D.; SERRANO-BARQUÍN, R.C.; GASTÓN, J.; CRUZ, G. and FAVILA, H. (2014): «Modelo Teórico-Metodológico para el estudio del turismo armónico y el desarrollo local». Investigaciones Turísticas, $\mathrm{n}^{\circ}$ 7, pp. 23-46.

PEARCE, D.G. (2012): Frameworks for Tourism Research. Wallingford, CABI.

RESILIENCE ALLIANCE (2007): Assessing and Managing Resilience in Social-Ecological Systems. Available in http://www.resalliance.org/3871.php

RUBIO, P. and SANZ, M.A. (Coord.) (2007): Investigación aplicada al desarrollo de territorios rurales frágiles. Zaragoza, Universidad de Zaragoza, Prensas Universitarias de Zaragoza.

SANCHO, J. and VERA, J.F. (Coord.) (2008): Turismo en espacios rurales y naturales. Madrid, Instituto Geográfico Nacional, Monografías del Atlas nacional de España.

SMITH, M. (2015): Issues in Cultural Tourism Studies. London, Routledge, 3th edition. 
STRICKLAND-MUNRO, J.K.; ALLISO, H.E. and MOORE, S.A. (2010): «Using resilience concepts to investigate the impacts of protected area tourism on communities». Annals of Tourism Research, No 37(2), pp. 499-519.

SECRETARÍA GENERAL DE TURISMO (2007): Plan de Turismo Español Horizonte 2020. Madrid, Ministerio de Industria, Turismo y Comercio. Available in http://www. tourspain.es/es-es/VDE/Documentos\%20Vision\%20Destino\%20Espaa/Plan_Turismo_ Espa\%C3\%B1ol_Horizonte_2020.pdf

TELFER, D.J. and SHARPLEY, R. (2008): Tourism and Development in the developing world. London, Routledge.

TORRES, A. (2013): «Turismo y sostenibilidad. Una propuesta metodológica para el estudio de la sostenibilidad turística a escala municipal». Investigaciones Turísticas, $\mathrm{n}^{\mathrm{o}} 5$, pp. 162-170.

TYRRELL, T.J. and JOHNSTON, R.J. (2008): «Tourism sustainability, resiliency and dynamics: Towards a more comprehensive perspective». Tourism and Hospitality Research, $\mathrm{n}^{\circ} 8(1), \mathrm{pp} .14-24$.

VERA, J.F.; LÓPEZ-PALOMEQUE, F.; MARCHENA, M. and ANTÓN, S. (2011): Análisis territorial del turismo y planificación de destinos turísticos. Valencia, Tirant lo Blanc.

WALKER, B.; GUNDERSON,L.; KINSIG, A.; FOLKE, C.; CARPENTER, S.; SCHULTZ, L. (2006): "A Handful of Heuristics and some Propositions for Understanding Resilience in Social-Ecological Systems». Ecology and Society, $\mathrm{n}^{\circ}$ 11(1). Available in http://www.ecologyandsociety.org/vol11/iss1/art13/

WILDING, N. (2011): Exploring community resilience in times of rapid change. Dunfermline, Carnegie UK Trust.

WILLIAMS, S. and LEW, A. (2015): Tourism Geography. Critical understandings of place, space and experience. London, Routledge, 3th edition.

WORLD TOURISM ORGANIZATION (2013): A Closer Look at Tourism. Sub-national Measurement and Analysis. Towards a Set of UNWTO Guidelines. Madrid, International Network on Regional Economics, Mobility and Tourism and the World Tourism Organization. Available in http://www.e-unwto.org/doi/pdf/10.18111/9789284414963

WORLD TOURISM ORGANIZATION (2015): Tourism Highlights. Available in http:// mkt.unwto.org/publication/unwto-tourism-highlights-2015-edition

XUNTA DE GALICIA (2010): Programa de desenvolvemento sostible do medio rural 2010-2014. Zonas definitivas. Axencia Galega de Desenvolvemento Rural - AGADER. Available in http://agader.xunta.es/UserFiles/File/PlanDesenvolvementoSostible/ ZonasDefinitivas.pdf

XUNTA DE GALICIA (2011): Lei 7/2011, de 27 de octubre, del turismo de Galicia. Diario Oficial de Galicia, ${ }^{\circ}$ 216, Viernes, 11 de noviembre de 2011. Available in http:// www.xunta.es/dog/Publicados/2011/20111111/AnuncioC3B0-041111-8318_es.html

XUNTA DE GALICIA (2014a): Plan Integral de Turismo de Galicia 2014-2016. Presentación de la Estratexia de Turismo de Galicia. Axencia de Turismo de Galicia. Available in http://issuu.com/turismodegalicia/docs/presentacion_plan_integral_turismo_fc 8 b734ba97d 20 
XUNTA DE GALICIA (2014b): Decreto 37/2014, de 27 de marzo, por el que se declaran Zonas Especiales de Conservación los Lugares de Importancia Comunitaria de Galicia y se aprueba el Plan director de la Red Natura 2000 de Galicia. Diario Oficial de Galicia, no 62, Lunes, 31 de marzo de 2014. Available in http://www.xunta.es/dog/ Publicados/2014/20140331/AnuncioCA02-270314-0001_es.html

XUNTA DE GALICIA (2015a): Sustentabilidade Territorial. Plan de Seguimento das DOT. Instituto de Estudos do Territorio, Conselleria de Medio Ambiente, Territorio e Infraestructuras. Available in http://www.cmati.xunta.es/seccion-organizacion/c/ Instituto_Estudos_Territorio?content=Direccion_Xeral_Sostibilidade_Paisaxe/Seguimento_DOT/seccion.html\&std=informe_2_PSST.html\&sub=Informes_PSST/

XUNTA DE GALICIA (2015b): Catalogo das Paisaxes de Galicia. Instituto de Estudos do Territorio, Conselleria de Medio Ambiente, Territorio e Infraestructuras. Available in http://www.cmati.xunta.es/seccion-organizacion/c/Instituto_Estudos_ Territorio?content=Direccion_Xeral_Sostibilidade_Paisaxe/Exposicion_publica_catalogo/seccion.html\&std=Descarga.$h t m l$ 